\title{
Pollution Management Through EnVironmental Permit - CASe StUdy
}

\author{
Tomislav Lukić, Nevenko Herceg \& Svjetlana Stanić-Koštroman
}
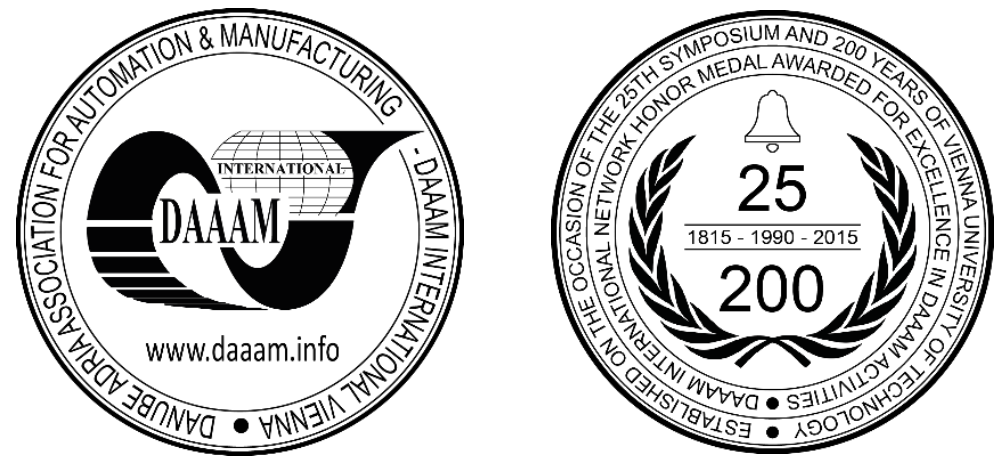

This Publication has to be referred as: Lukic, T[omislav]; Herceg, N[evenko] \& Stanic-Kostroman, S[vjetlana] (2016). Pollution Management Through Environmental Permit - Case Study, Proceedings of the 27th DAAAM International Symposium, pp.0860-0865, B. Katalinic (Ed.), Published by DAAAM International, ISBN 978-3-902734-08-2, ISSN 1726-9679, Vienna, Austria

DOI: $10.2507 / 27$ th.daaam.proceedings. 124

\begin{abstract}
Processing industry in Bosnia and Herzegovina had been developed by 1991 in several centers. In the postwar period, the majority of industrial plants were extinguished with only the most productive sectors remaining as carriers of development, but their priority was not the environmental protection. The adoption of the Law on Environmental Protection ("Official Gazette of the F B\&H", number 33/03 of 19 July 2003) involving the European Directive IPCC (Integrated Pollution, Prevention and Control) created the preconditions for an integrated approach to preventing and supervising of pollution and practical application of a new legal instrument - environmental permit. First environmental permits were issued in 2004, and up to date some 900 permits have been put into force in the Federation of Bosnia and Herzegovina. With this paper we want to show the effect of the administrative procedure of issuing environmental permit on the development of integral system of environmental protection of the Federation of Bosnia and Herzegovina, and to emphasize the need of changing the existing legislation in this sector.
\end{abstract}

Keywords: Federation of Bosnia and Herzegovina; environment; environmental permit; industry; pollution

\section{Introduction}

In the socialist Yugoslavia, Bosnia and Herzegovina was the second most underdeveloped republic only after Macedonia. The population occupied themselves with agriculture, especially in Posavina and in the part of Herzegovina, and this only on the farms which were small and unprofitable while food was mainly imported. What was favored was heavy, processing and military industry with especially developed special-purpose industry in the field of armament, military vehicles and equipment. Not legging behind were other industrial branches such as mining, ferrous metallurgy and steel production, aluminum production, machine building, paper, textile and wood industries. The care of environment was symbolic, resulting in quite a number of accumulated industrial refuse dumps while emissions into the air, water and soil were enormous. An additional damage to the environment was caused by the war in Bosnia and Herzegovina which was waged from 1992 to 1995 . The war conflicts destroyed the economy and infrastructure of Bosnia and Herzegovina, and the production recorded an $80 \%$ fall. In the postwar period, starting with 1995, the production started to recover but 
with a growth rather slowed down. The private initiative started to emerge with a part of state companies undergoing privatization. However, the consequences of centrally planned economy in the socialist Yugoslavia are felt even today, and one of the key problems was a very large number of employees in industry. Due to an unstable political situation and the division of the country into two entities and a district, the growth of the GDP was not at a satisfactory level in the next ten years, and B\&H became one of the most polluted countries in the region.[1], [2].

In cooperation with EU, in 2003 legislature institutions of B\&H enacted a set of laws which were to a greater extent adjusted to EU directives, whereby the preconditions were created for the interventions of the state into the environment. According to the F B\&H Constitution, Chapter III, Article 2, Indent c), the environmental protection policy is in the joint jurisdiction of the Federation of Bosnia and Herzegovina and cantons. [3]. In the F B\&H Constitution there is no explicit provision defining the competence for sustainable development, but Chapter III, Article 1, Indents d) and i) stipulates that the making of economic and energy policies is the exclusive responsibility of the Federation of Bosnia and Herzegovina. The set of laws from 2003 regulating the field of environmental protection in the Federation of Bosnia and Herzegovina includes: Law on Environmental Protection, Law on Water Protection, Law on Air Protection, Law on Waste Management, Law on Nature Protection and Law on Environmental Protection Fund. The water management and protection is covered by the Law on Waters ("Official Gazette of the F B\&H", number 70/06). However, the sublegislation prescribed by certain laws does not exist, and for example out of 23 by-laws, whose adoption is prescribed by the Law on Environmental Protection, only 10 have been adopted. One of the major activities on adjusting B\&H legislation to the European Union legislation is the introduction of an integrated approach to preventing and supervising of pollution based on IPPC directive (Integrated Pollution Prevention and Control Directive). A new legal document called Environmental Permit with its legal instruments in the form of the provisions in the Law on Environmental Protection ("Official Gazette of the F B\&H", number 33/03 and 38/09) and implementation regulations should act as prevention against excessive environmental protection. [4], [5].

Environmental Permit is based on the acquisition of the European Union legislation, in this case of the so called horizontal legislation and EU directives: EIA Directive 85/337/EEC, Supplementary Directives 97/11/EC and 2003/35/EC, SEA Directive 2001/42/EC, Directive on Public Access to Environmental Information 2003/4/EC as well as EU Directive on Industrial Pollution Control, IPPC Directive 96/61/EC with the supplement of Directive 2003/35/EC 2003/87/EC and Regulations EC/1882/2003 and EC/166/2006, then COMAH Directive 96/82/EC and LCP Directive 2001/80/EC [6].

Some of the implementation by-laws regulating the area of environmental permit issuance are:

- Ordinance on plants and facilities that require environmental impact assessment and on plants and facilities which can be constructed and put into operation only subject to environmental permit ("Official Gazette of the F B\&H”, number: 19/04),

- Ordinance on the conditions for the submission of the request for the issuance of environmental permit for plants and facilities which had been granted a permission before coming into force of the Law on Environmental Protection ("Official Gazette of the F B\&H", number: 45/09 i 43/10),

- Ordinance on deadlines for submitting the request for the issuance of permit for plants and facilities which had been granted a permission before coming into force of the Law on Environmental Protection ("Official Gazette of the F B\&H”, number: 68/05 and 43/10),

- Ordinance on Registers on plants and pollutions (“Official Gazette of the F B\&H”, number: 82/07).

All plants which produce or may produce loads on the components of the environment are obliged to provide a working permit or environmental permit in a short time. This permit obliges them to adept their operations to the most effective and most advanced levels of development of the activity and related modes of production and maintenance of plants available to the operator, which adaption must be based on the demands of the best available technique - so called BAT (Best Available Technique) [4]. Pursuant to the provisions of Article 87 of the Law on Environmental Protection ("Official Gazette of the F B\&H", number 33/03 and 38/09) and Ordinance on adopting the best available technique to achieve environmental quality standards, the Federal Ministry of Environment and Tourism passed a decision adopting Technical instructions for the best available techniques of BAT documents for six sub-sectors of food processing industry and agriculture:

- 1. Slaughterhouses for Bovine Cattle

- 2. Meet Processing,

- 3. Fish Processing,

- 4. Fruit and Vegetable Processing,

- 5. Milk Production and Processing

- 6. Beer Production and

- 7. Fish Growing.

Obligations that environmental legislation imposes on economy, related to the obligation of environmental permit acquisition, meeting the requirements for waste management, obligation of monitoring, reporting and compensation for the damage done, have already largely become a reality. Clear responsibility for the consequences on the environment prescribed by environmental permit imposes a number of new responsibilities for companies, financially demanding, but 
profitable in the long run. However, what should be additionally improved is certainly the change of the existing perception according to which socially responsible business operations are considered as the fulfillment of legal obligation. What will help in this matter is certainly the interest of the public in the environmental issues, especially through the engagement of the NGO sector which from the regulatory bodies and economy requires greater engagement and investments in environmental protection. [4], [7].

\section{Environmental Permit}

Environmental permit is integral administrative act prescribing measures for the protection of all environmental components: air, water, soil, biological diversity, waste management etc., for the purpose of achieving a high level of their protection. In the legal proceedings preceding the issuance of town-planning permit, the investor whose project is considered to have or may have a negative impact on the environment is obliged to obtain environmental permit beforehand.

In the Federation of $\mathrm{B} \& \mathrm{H}$ this permit should be obtained in the following cases:

- Construction and putting into operation new plants and facilities where the aim is for the investor to anticipate, in the earliest phase of the project development, the measures for preventing a negative effect the project may have on the environment, most often in agreement with the Study on the environmental impact assessment,

- The existing plants and facilities which had been granted permits before coming into force of the 2003 Law on Environmental Protection, where an adjustment to the environmental protection standards is carried out through the Plan of Activities with measures and deadlines for gradual reduction of emissions,

- Devastated plants as well as plants and facilities out of operation, which had been granted permits before coming into force of the 2003 Law on Environmental Protection, and

- In case of major changes in the operation of existing facilities subject to the issuance of environmental permit [4], [7].

By the implementation regulation and Ordinance on plants and facilities that require environmental impact assessment and on plants and facilities which can be constructed and put into operation only subject to environmental permit ("Official Gazette of the F B\&H”, number: 19/04) a special control regime and records of the activities as per branches of economy that endanger or may endanger environment have been regulated for new plants and facilities. Also, in its separate chapters this Ordinance defines the content of the study on environmental impact assessment as well as criteria assessing the need for the environmental impact assessment implementation. According to the said Ordinance and classification of plants and facilities by types, quantity, capacity and other criteria, environmental permit is issued by the Federal Ministry of Environment and Tourism, while for other plants with parameters below the said quantities and capacities and/or other criteria, for middle-sized and small plants and facilities, permit is issued by the competent cantonal ministries (Article 2 of the Ordinance). For very small plants and facilities environmental permit is not required, rather the conditions and environmental protection measures are determined within a town-planning consent and building permit issued by a municipality. Allowing for the need of companies to adjust their operations to the Law requirements, interim periods and the conditions for the environmental permit acquisition have been envisaged. One of the key conditions is the Plan of Activities for those plants to which the adjustment to the European standards causes considerable changes and adjustment deadlines for the permit to be obtained. [4], [7].

Environmental Permit contains:

- marginal values for the emissions of polluting substances,

- measures for the reduction of emissions in order to protect air, soil, water, plants and animals,

- measures for the management of the waste produced by plants and facilities,

- protection measures against noise,

- measures for the reduction or cessation of the cross-border pollution,

- monitoring system with the defining of methodology and measuring frequency.

- conditions and measures for the prevention of accidents on a larger scale and

- rehabilitation measures upon work completion, in other words measures for the restoration of the environment.

When considering the request for the issuance of environmental permit, the Ministry takes into account the following criteria:

- project characteristics: size, amassment with other structures, exploitation of natural resources, waste production, pollution and disturbances, accident risks etc.,

- project location and the sensitivity of the environment of the geographic areas which may also be affected by the project: the present use of land, availability, quality and regenerative capacity of natural resources, absorption capacity of natural ecosystem (wetlands, coastal zones, protected areas etc.),

- The characteristics of the possible effects: the scope of the effect, cross-border nature of the effect, the size and complexity of the effect, the frequency and reversibility. 
Environmental permits are issued for a period of five years. The owner of the plant (operator) is obliged to perform the prescribed monitoring and send the results to the competent ministry. If in the set period the operator fails to fulfill the set obligations for environmental protection, the competent ministry will revoke the issued permit. Also, upon the expiry of a five-year period, all operators are obliged to apply for the issuance of a new environmental permit. This approach ensures:

- the possibility of survival and development of enterprises, preservation of jobs and fulfillment of obligations towards broader social community,

- the possibility of planning and implementing of world-wide accepted environmental protection measures in the interim period of five years under the supervision of planned measures by the competent ministries of environment and inspection,

- the information of the public about the impact of the enterprises on environment as prescribed in the Law on Environmental Protection, and

- the reduction of the harmful effects on the environment and the reaching of the levels of protection prescribed by EU Directives and Guidelines.

With legislation like this, B\&H started to come nearer to the EU environmental policy faster than some other countries in the region. [4], [7]. This is corroborated by the latest records in the data basis which the Federal Ministry of Environment and Tourism updates and in a transparent way presents to the Government of the Federation of B\&H and the public by means of the reports and on its web-site: www.fmoit.gov.ba.

\section{Statistics about Issuing of Environmental Permits in the Federation of B\&H}

In the period from 2004 to 2016, the Federal Ministry of Environment and Tourism issued a total of 892 environmental permits in its competence (Fig 1). As we deal here with quite a new administrative procedure, at the very beginning, that is in 2004 only five permits were issued. However, by the end of 2015 their number rose up to more than a hundred permits a year. Considering the complexity of the administrative procedure, of acquisition of legally prescribed documents, and especially concerning harmonization with area-planning documents of the municipality on whose territory the plant-facility is situated, procurement of opinions of competent authorities, as well as preceding actions in the procedure which include the evaluation of the Study of environmental impact assessment for new installations or the evaluation of acceptability of Plans of Activity as adjustment plans for existing plants and facilities, [4], [7], we can conclude that the number of issued permits at the Federal level is very good. The said studies with waste management plans are evaluated by expert commissions. At the same time, in this complex procedure it is necessary to follow the procedure of procuring the prior water consent on meeting water conditions or acquisition of water consent.

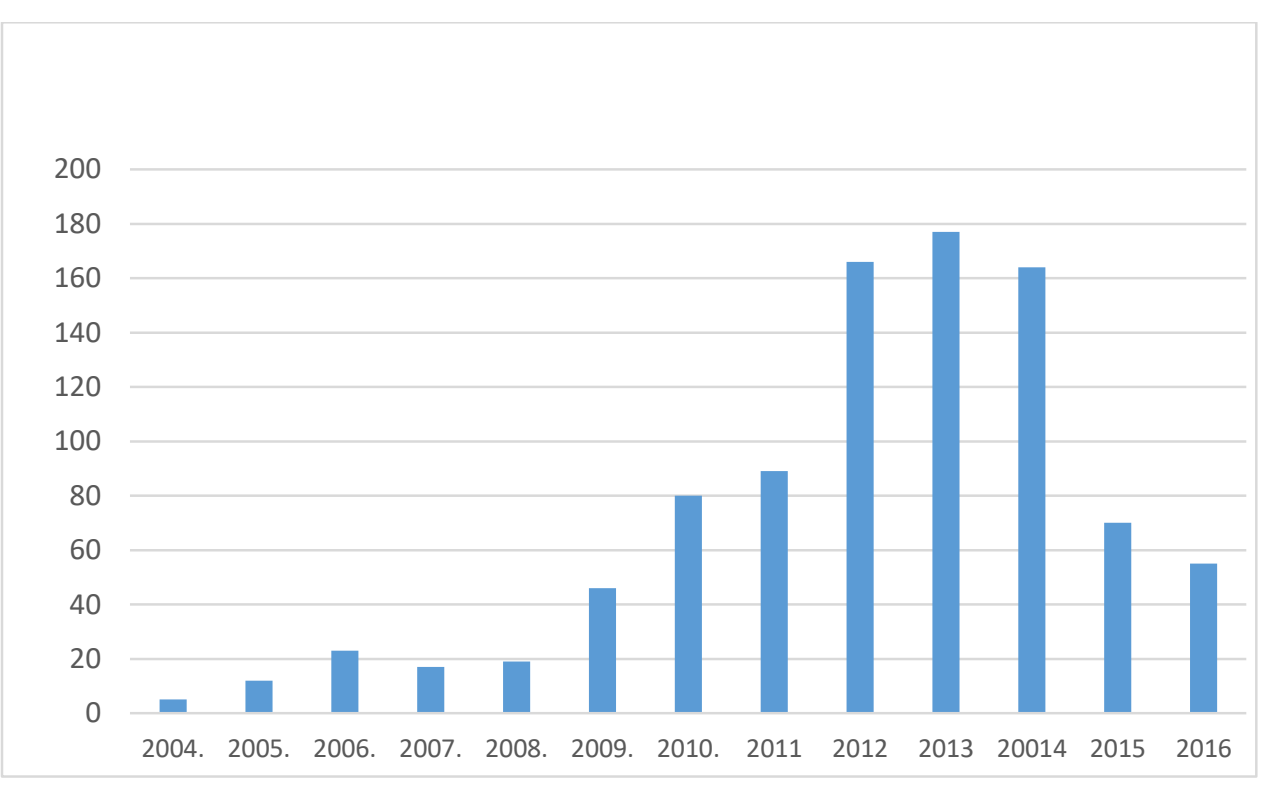

Fig 1.The number of issued environmental permits at the federal level of competence in the 2005-2016 period.

The Sector for the issuance of environmental permits within the Federal Ministry of Environment and Tourism is under staffed. Despite this, the number of issued environmental permits in the Federation of Bosnia and Herzegovina is very high (Fig 1, Table 1). European average for the issuance of environmental permits is four permits per an employee, and by comparing these standards with the number of employees in the federal and cantonal ministries of environment it can be concluded that the results are above average. 


\begin{tabular}{|l|c|}
\hline Canton & $\begin{array}{c}\text { The number of issued } \\
\text { environmental } \\
\text { permits }\end{array}$ \\
\hline Canton 1. Una-Sana (USC) & 360 \\
\hline Canton 2. Posavina (PC) & 49 \\
\hline Canton 3. Tuzla (TC) & 441 \\
\hline Canton 4. Zenica-Doboj (ZDC) & 331 \\
\hline Canton 5. Bosnia-Podrinje (BPC) & 37 \\
\hline Canton 6. Central-Bosnia (SBC) & 154 \\
\hline Canton 7. Herzegovina-Neretva (HNC) & 254 \\
\hline Canton 8. Western Herzegovina (ZHC) & 41 \\
\hline Canton 9. Sarajevo Canton (SC) & 157 \\
\hline Canton 10. Hercegbosnia (HBC) & 15 \\
\hline & $\mathbf{1 8 3 9}$ \\
\hline
\end{tabular}

Table 1 The number of environmental permits at the cantonal level of competence issued by 2015

Analyses have shown that up to date, as per branches of economy, the majority of environmental permits have been issued in the energy sector, the sector of excavating industries (mainly quarries and mines), then chemical, metal and food processing industries, waste management, infrastructure, textile, leather, wood and paper industries, tourism, water management etc. [4], [7], [8], [9].

However, many enterprises have not started the procedure of acquisition of environmental permits yet whether it be the federal or cantonal competence and in many cases for the objective reasons which can be summarized as follows:

- non-existence of sector strategies,

- non-compliance of sector/department policies with the new legal obligations regarding environmental permit acquisition,

- inadequate privatization procedure of enterprises from the environmental permit acquisition point of view,

- low level of consciousness and financial unpreparedness of enterprises for the implementation of legal procedure for environmental permit acquisition,

- the complexity of the administrative procedure for the issuance of environmental permits, and

- the lack of experience for the implementation of such a complex administrative procedure.

The advantages of environmental permit for the economy and the overall state of the environment in the Federation of $\mathrm{B} \& \mathrm{H}$ are great, and they are reflected in the following:

- It contributes to a complete observation of business processes and their impacts on the environment as well as to a transparent presentation of the data on such impacts,

- It works as a binding element, because representatives of all organizational units must participate in its preparation: from procurement and planning to production, maintenance and sale,

- It is good for the representatives of public authorities (local and regional self-governments, inspection bodies, legal persons with public authorities etc.) because of integrating, harmonizing and uniting of all the important data for the plant (farm, waste dump) in one document,

- The procedure in the case of a plant close-down is also described,

- An obviously interested public, which as a rule is included in the very procedure of the issuance of the environmental permit,

- Strengthened consciousness of a company management on the implementation of the conditions from the environmental permit,

- Improved quality condition of all the environmental components,

- The damage inflicted on the protected plant and/or animal species and their habitats as well as to landscape, water, sea, soil and Earth's crust has been significantly reduced, and

- The risk for the life and health of people living near these plants has been reduced [4], [7]. 


\section{Conclusion}

Judging from the experiences in the last 13 years, since the existence of a new legal frame and some 40 implementing regulations in the field of environmental protection, it can be concluded that $\mathrm{B} \& \mathrm{H}$ is entering the circle of European countries which implement systematic environmental protection. The Law on Environmental Protection contains regulations on integrated framework for the issuance of environmental permits based on the concept of integrated pollution prevention and control (IPPC). Ordinances, directives and instructions have been adopted to prescribe the method that plants and facilities are obliged to follow in order to fulfill all the requirements for the environmental permit acquisition.

The quality of this systematic approach is based on the creation of an obligatory environmental legal act environmental permit, which instigates the prevention and control of pollution management procedure not only for new plants, but also for the existing ones that with their technologies must gradually adapt to new stricter requirements regarding the reduction of pollution levels and application of the new pollution thresholds prescribed by the law. In that way, the procedure of the remediation of the environment in B\&H and work ambient will be gradually carried out, creating more favorable business space which encourages responsible management and technological processes control in order to reduce excessive environmental pollution.

\section{References}

[1] Herceg, N. (2009). The State of the Environment in the Federation B\&H, the Federal Ministry of Environment and Tourism, Sarajevo

[2] The Ministry of Commerce and Economic Relations of Bosnia and Herzegovina (2012). The Report on the State of the Environment in Bosnia and Herzegovina, Sarajevo

[3] Official Gazette FB\&H, nos. 1/94, 13/97, 16/02, 22/02, 52/02, 63/03, 9/04, 20/04, 33/04, 71/05, 72/05 and 88/08.

[4] Herceg, N.; Rudež, M.; Lukić, T. \& Bandur, M. (2011). Environmental Permit - Systematic Approach to Pollution Management and Legal Guarantee of the Environmental Protection in Bosnia and Herzegovina, XII International Symposium on Quality "With Quality to Business Excellence”, Osijek

[5] Herceg, N. \& Cero, M. (2009). Environmental EU Acquis in Federation B\&H, state and perspective, International scientific thematic conference "Soil Protection Activities and Soil Quality Monitoring in South Eastern Europe", Sarajevo

[6] Herceg, N. (2009). Environmental Policy through the Strategy of the Environmental Protection. Modern issues, Vol. 4, No. 7, (May, 2009)

[7] Herceg, N. (2010). The Challenges of the Environmental Permit, the Federal Ministry of Environment and Tourism, Sarajevo

[8] Herceg, N \& Rudež, M. (2010). The Importance of the Environmental Permit and the Waste Management Plan in Prevention and Waste Disposal Control in B\&H, International Conference "Management of Dangerous and Harmless Waste in the Region", Zenica

[9] Herceg N. \& Cero, M. (2010). Waste in the Report on the State of the Environment in the Federation B\&H, International Conference "Management of Dangerous and Harmless Waste in the Region", Zenica

[10] Herceg, N. (2013). Environment and Sustainable Development, University of Mostar/Synopsis Zagreb, MostarZagreb 